EWELINA K. NIEMCZYK

ORCID 0000-0002-9381-5449

North-West University

Republic of South Africa

Marzanna PogorzelsKa

ORCID 0000-0001-7346-4023

Uniwersytet Opolski

\title{
KSZTAŁCENIE BADAWCZE W CZASACH GLOBALIZACJI Z PERSPEKTYWY EUROPEJSKIEJ
}

Aвstract. Niemczyk Ewelina K., Pogorzelska Marzanna, Kształcenie badawcze w czasach globalizacji z perspektywy europejskiej [Research Education in Global Times: A European Perspective]. Studia Edukacyjne nr 55, 2019, Poznań 2019, pp. 205-221. Adam Mickiewicz University Press. ISSN 1233-6688. DOI: $10.14746 /$ se.2019.55.12

This qualitative research study takes a closer look at developing competent researchers and thus building research capacity within Europe. The rapidly changing research environment driven by globalisation, internationalization, technological advancements, and the use of innovative methodologies impacts how research is designed, conducted, and reported on. We argue that the current complex research environment calls for globally competent researchers able to engage in research projects and research communities across disciplines and across geographic borders. However, there is scarce empirical evidence about research knowledge and competencies which global researchers need to conduct quality research. Relevant literature is also almost silent on what kind of educational opportunities within higher education institutions allow graduate students to acquire these competencies. To address the existing gap in the literature, this article brings perspectives of twenty-three novice and experienced scholars from ten European countries. The findings showcase a spectrum of competencies required by globally competent researchers as well as opportunities and challenges associated with the acquisition of these competencies. According to the respondents, efforts need to be maximized to build research capacity via emerging talents. This implies paying close attention to the research learning spaces, practices, and polices where future globally competent researchers can be nurtured and shaped. Considering the small sample size of participants, the findings are not meant to be conclusive but rather informative in nature for those involved in research.

Key words: globally competent researchers, research education, research competence, qualitative study, European context 


\section{Środowisko badawcze w czasach globalizacji}

Współcześnie, w ramach globalnej gospodarki opartej na wiedzy, dostrzega się wzrastające znaczenie innowacyjności i kompetencji badawczych jako istotnych warunków sprzyjających rozwojowi społeczno-ekonomicznemu poszczególnych krajów ${ }^{1}$. W konsekwencji, w wielu państwach traktujących uniwersytety jako instytucje kluczowe $\mathrm{w}$ budowaniu konkurencyjności kraju zwiększono nakłady związane z finansowaniem badań i przygotowaniem naukowców². Jak wskazuje The Association of Commonwealth Universities, prowadzenie badań wysokiej jakości stanowi obecnie najważniejszy element misji większości uniwersytetów, choć jednocześnie wskazuje się, że powodzenie owej misji może być osiągnięte jedynie jeśli inwestuje się w osoby odpowiedzialne za prowadzenie badań ${ }^{3}$.

$\mathrm{Z}$ wymogami światowej konkurencji związane są tworzone nieustannie rankingi uniwersytetów ${ }^{4}$, których istnienie odzwierciedla wzrastający nacisk na rezultaty badań poszczególnych krajów oraz kojarzony z nimi poziom innowacyjności ${ }^{5}$. Ów nacisk jest widoczny w „wyłanianiu się globalnego modelu" uniwersytetu badawczego, cechującego się niespotykaną wcześniej intensywnością badań i rozwoju naukowego ${ }^{6}$. Jak wskazują wytyczne Komisji Europejskiej (2015):

Aby móc konkurować w skali globalnej, potrzebujemy więcej osób, które będą podążały drogą kariery naukowej i którym następnie zapewni się bazę do zatrudnienia na

${ }^{1}$ Economic and Social Research Council, Strategic plan 2009-2014, 2014, Swindon, UK, http:/ / www.esrc.ac.uk/news-and-events/publications/strategic-plan/index.aspx, [data dostępu: 13.02. 2018]; European Commission, PEOPLE: Training and career development of researchers, 2015, http:// ec.europa.eu/research/fp7/index_en.cfm?pg=people, [data dostępu: 13.02.2018]; F. Hallet, P. Fidalgo, Educational research capacity building in the European Union: A critique of the lived experiences of emerging researchers, European Educational Research Journal, 2014, 13, s. 425-433.

2 I. Chubb, Productivity, industry engagement and the PhD workforce, Keynote address for the AMSI Accelerate Australia Conference, Melbourne February 2013, http://www.chiefscientist. gov.au/2013/02/productivity-industry-engagement-and-the-phd-workforce/, [data dostępu: 13.02.2018].

${ }^{3}$ The Association of Commonwealth Universities, Investing in the next generation of researchers, London, 2016, s. 2, https://www.acu.ac.uk/publication/download?publication=676, [data dostępu: 13. 02. 2018].

${ }^{4}$ R. Deem, K.H. Mok, L. Luca, Transforming higher education in whose image? Exploring the concept of the 'world-class' university in Europe and Asia, Higher Education Policy, 2008, 21/1, s. 83-97.

${ }^{5}$ D. Boud, A. Lee, Framing doctoral education as practice, [w:] Changing practices of doctoral education, red. D. Boud, A. Lee, Abingdon 2009, s. 10-27; H. Connell (red.), Part 1: Addressing the research challenge in higher education, [w:] University research management: Meeting the institutional challenge, Paris 2004, s. 15-63.

${ }^{6} \mathrm{~K}$. Mohrman, W. Ma, D. Baker, The research university in transition: The emerging global model, Higher Educational Policy, 2008, 21, s. 5-27. 
otwartym rynku pracy. Europa musi stać się atrakcyjnym kontynentem, który wspiera innowacje i tworzenie wiedzy i który zachęca naukowców do pozostania7.

Jednocześnie nie ulega wątpliwości, że zarówno zawód naukowca, jak i sposoby badań podlegają ciągłym zmianom. Praktyki badawcze zachęcają do nowych sposobów zbierania danych i upowszechniania rezultatów badań, komunikacji wewnątrz i pomiędzy społecznościami badawczymi, tworzenia interdyscyplinarnych i międzynarodowych sieci współpracy, upowszechniania wyników badań wśród środowisk pozanaukowych. Tego rodzaju postęp skutkuje zapotrzebowaniem na nowe narzędzia, umiejętności i podejścia do kształcenia globalnie kompetentnych naukowców, zdolnych do zaangażowania się $\mathrm{w}$ studia badawcze biegnące $\mathrm{w}$ poprzek granic wyznaczanych przez poszczególne dyscypliny, czy też uwarunkowania geograficzne. Rządy wielu państw, instytucje grantodawcze i uniwersytety, skupione na promowaniu silnych projektów badawczych, nieustannie inicjują działania i wprowadzają regulacje, których celem jest przyciągnięcie uzdolnionych naukowców z zagranicy oraz szkolenie kolejnej generacji kompetentnych naukowców (służą temu np. granty podyplomowe dla zagranicznych studentów i stypendia podoktorskie, czy atrakcyjne pakiety dotyczące zatrudnienia dla uznanych naukowców).

Jednocześnie, choć edukacja wyższa pełni kluczową rolę w kształceniu przyszłych naukowców zdolnych do spełnienia oczekiwań tworzonych przez zglobalizowaną rzeczywistość ${ }^{8}$, to wiedza dotycząca skutecznych sposobów wspierania kompetencji potrzebnych w osiąganiu badawczej i naukowej doskonałości jest dość ograniczona9. W dostępnej literaturze można znaleźć odniesienia do niektórych kompetencji wykraczających poza umiejętności ściśle badawcze i wiedzę naukową, które mogą być potrzebne badaczom XXI wie$\mathrm{ku}$, funkcjonującym w świecie wzajemnych relacji. Należy do nich umiejętność komunikowania się pomiędzy badaczami różnych dyscyplin ${ }^{10}$, umiejętność tłumaczenia badań wielojęzycznych ${ }^{11}$, zdolność zdobywania funduszy międzynarodowych ${ }^{12}$, świadomość warunkowanej kontekstem etyki ${ }^{13}$. Nie-

${ }^{7}$ European Commission, PEOPLE: Training and career development of researchers, 2015. http:/ / ec.europa.eu/research/fp7/index_en.cfm?pg=people, [data dostępu: 13.02.2018].

8 P. Lamblin i in., Skills and competencies needed in the research field: Objectives 2020, APEC/ Deloitte, Paris 2010, https://recruteurs.apec.fr/files/live/mounts/media/medias_delia/documents_a_telecharger/etudes_apec/skills_and_competencies_needed_in_the_research_field_ objectives_2020/6185e35c6eef813aadaf2ee2bac10c6c.pdf [data dostępu: 23.02.2018].

${ }_{9}$ G.E. Walker i in., The formation of scholars: Rethinking doctoral education for the twenty-first century, San Francisco 2008, s. 151.

${ }_{10}$ P. Lamblin i in., Skills and competencies needed in the research field.

${ }^{11}$ B. Weijters, M. Geuens, H. Baumgartner, The effect of familiarity with the response category labels on item response to Likert scales, Journal of Consumer Research, 2013, 40, s. 361-381.

${ }^{12} \mathrm{P}$. Lamblin i in., Skills and competencies needed in the research field.

${ }^{13}$ M.K. McGinn, S.A. Tilley, Research ethics on the ground: Partnerships, practices, and plans in global population health - A collective case study of ethics issues and challenges. Paper presented 
mniej jednak, odniesienia dotyczące tego, które praktyki w ramach edukacji wyższej przyczyniają się do nabycia powyższych kompetencji pojawiają się w literaturze bardzo rzadko.

Prezentowany tekst, oparty na analizie jakościowej, ma na celu: a) zaprezentowanie wiedzy i umiejętności wymaganych od naukowców kompetentnych $\mathrm{w}$ aspekcie globalnym, zdolnych do prowadzenia badań o wysokich standardach etycznych oraz b) zbadania możliwości i wyzwań związanych z nabywaniem tychże kompetencji w kontekście europejskiej edukacji wyższej.

\section{Zagadnienia terminologiczne}

Pojęcie kształcenie badawcze (ang. research education) odnosi się do przestrzeni i praktyk, których celem jest wyposażenie przyszłych oraz początkujących badaczy $\mathrm{w}$ wiedzę, umiejętności i postawy potrzebne do prowadzenia przez nich badań o wysokim standardzie etycznym w skali lokalnej i globalnej

Termin przestrzenie kształcenia badawczego (ang. research education spaces) dotyczy możliwości kształcenia badawczego, które pozwalają studentom zwiększać ich wiedzę i umiejętności badawcze oraz kształtować odpowiedzialność związaną z funkcjonowaniem jako badacz. W kontekście europejskim, przestrzenie kształcenia badawczego w programach studiów podyplomowych mogą zawierać: kursy metodologiczne, zajęcia poświęcone poszukiwaniu tematu badawczego pracy, podczas których student podejmuje niezależne badanie pod opieką promotora, asystentury lub warsztaty badawcze pozwalające studentom towarzyszyć opiekunom badawczym w realizacji ich projektów.

Termin badacze/naukowcy kompetentni w aspekcie globalnym (ang. globally competent researchers; $\mathrm{w}$ dalszej części tekstu na oznaczenie zwrotu badacze/ naukowcy kompetentni w aspekcie globalnym będzie używany skrót angielskiego tłumaczenia: GCR) został wprowadzony przez E. Niemczyk w 2015 roku, w związku z przeprowadzanymi przez nią badaniami, które zostały opublikowane w 2018 roku $^{14}$. Poniższy cytat odnosi się do wyłonionej definicji omawianego pojęcia:

Badacz kompetentny w aspekcie globalnym [GCR - przyp. aut.] jest w posiadaniu wiedzy, umiejętności, systemu wartości i podejścia niezbędnych do przeprowadza-

at Innovations in Global Health Research - Global Social Justice and the Social Determinants of Health: Setting the Course for the Future, Ottawa, ON, October 2012; R. Szostak, Research skills for the future: An interdisciplinary perspective, Journal of Research Practice, 2013, 9(1), Article V3, http://jrp.icaap.org/index.php/jrp/article/view/385/308, [data dostępu: 13.02.2018].

${ }_{14}$ E.K. Niemczyk, Developing Globally Competent Researchers: International Perspective, South African Journal of Higher Education, 2018, 32(4). 
nia badań o wysokim stopniu etyczności i naukowego rygoru w zróżnicowanych środowiskach. Tacy badacze są świadomi szerokiego, globalnego kontekstu w którym funkcjonują oraz istotnych kwestii wpływających na edukację w zróżnicowanych środowiskach. Są także zaangażowani we współpracę w wielokulturowej i interdyscyplinarnej rzeczywistości. Badacze kompetentni w aspekcie globalnym wysoko cenią różnorodność, sprawiedliwość społeczną, prezentując przy tym postawę wrażliwości międzykulturowej na wszystkich etapach procesu badawczego ${ }^{15}$.

Według Niemczyk, powyższa definicja umożliwia bardziej holistyczną refleksję dotyczącą kompetentnych badaczy prowadzących badania w zróżnicowanych środowiskach i funkcjonujących w perspektywie globalnej. Ponadto, zaprezentowana definicja może posłużyć jako punkt wyjścia do: a) określenia oczekiwań wobec badaczy kompetentnych w aspekcie globalnym, b) oceny, czy sami badacze identyfikują się jako kompetentni w aspekcie globalnym, c) ustanowienia wytycznych dotyczących programów badawczych przygotowujących początkujących naukowców do prowadzenia badań w zglobalizowanym świecie, d) zapewnienia przestrzeni badań i rozwoju dla czynnych badaczy, jako przyszłych ekspertów w opisywanym aspekcie.

\section{Metodologia przeprowadzonych badań}

Prezentowany tekst oparty jest na toczącym się na dużą skalę międzynarodowym projekcie, którego celem jest analiza koncepcji globally competent researcher i kompetencji, które taka osoba powinna posiadać, aby móc zaangażować się w międzynarodowe, interdyscyplinarne i międzysektorowe projekty. Przedstawione badanie jakościowe jest zakorzenione w podejściu interpretatywnym, w którym

znaczenie jest ujawniane, odkrywane i doświadczane, nacisk kładziony jest na tworzenie sensów, opis i detale związane z danym zjawiskiem, a sam proces tworzenia znaczenia jest uważany za podstawowy cel tychże badań, skoncentrowanych na rozumieniu zjawisk społecznych ${ }^{16}$.

Będąc częścią większego studium badawczego, niniejszy tekst powstał na podstawie odpowiedzi na obszerny, zawierający pytania otwarte, kwestionariusz wypełniony przez 23 początkujących i doświadczonych badaczy kwestii edukacyjnych z 10 krajów europejskich, będących członkami Stowarzyszenia Edukacji Porównawczej w Europie. Wśród uczestników badania znalazło się ośmiu profesorów, ośmiu naukowców po doktoracie,

${ }^{15}$ Tamże.

${ }^{16}$ L.M. Given, Interpretive Research, [w:] The SAGE encyclopedia of qualitative research methods, red. L. M. Given, Thousand Oaks 2008, s. 465. 
siedmiu studentów studiów doktoranckich, reprezentujących obydwie płcie, choć w nierównych proporcjach (16 kobiet i 7 mężczyzn). Respondenci wywodzili się z różnych dyscyplin związanych z edukacją i prezentowali zróżnicowane zainteresowania badawcze.

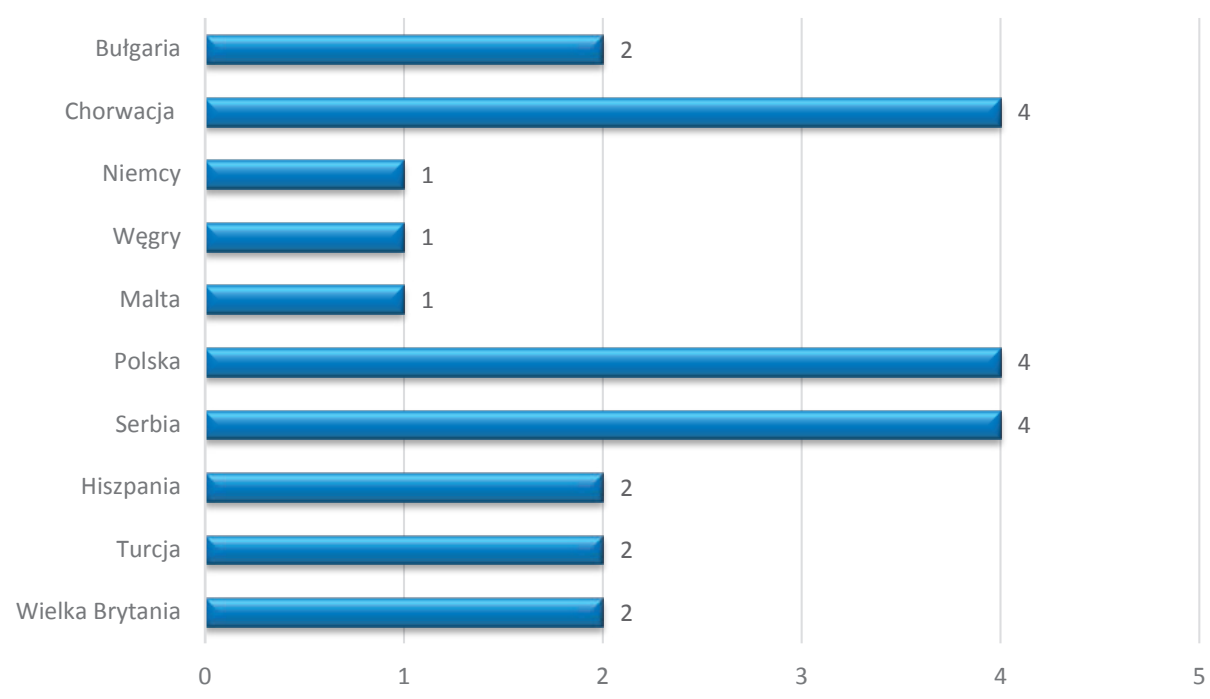

Ryc. 1. Pochodzenie respondentów

(źródło: badanie własne)

Dane zostały zebrane w języku angielskim między czerwcem i lipcem 2016 roku za pomocą survey monkey. Analiza danych obejmowała przestudiowanie odpowiedzi udzielonych w 23 kwestionariuszach z pytaniami otwartymi i zakodowanie tekstu pod kątem celów niniejszego tekstu, takich jak analiza: a) wiedzy, umiejętności i wartości wymaganych od GCR w celu prowadzenia badań o wysokiej jakości oraz b) możliwości i wyzwań związanych z nabywaniem tychże kompetencji. Proces kodowania polegał na wygenerowaniu wstępnych kodów, pogrupowaniu kodów reprezentujących podobne znaczeniowo odpowiedzi i ustalenie końcowej liczby wyłonionych tematów ${ }^{17}$. Dla celów niniejszego tekstu, opinie osób uczestniczących zostały skategoryzowane $\mathrm{w}$ trzech wzajemnie połączonych tematach:

1. Wiedza i umiejętności oczekiwane od GCR

2. Możliwości edukacyjne związane z przygotowaniem GCR

3. Wyzwania związane z przygotowaniem GCR

${ }^{17}$ V. Braun, V. Clarke, Using thematic analysis in psychology, Qualitative Research in Psychology, 2006, 3 (2), s. 77-101, http://dx.doi.org/10.1191/1478088706qp063oa, [data dostępu: 13.02.2018]. 
Prezentacja każdej kategorii jest uzupełniona fragmentami odpowiedzi osób uczestniczących tak, aby zapewnić autentyczność przedstawianych rezultatów. Wybrano przy tym najbardziej reprezentatywne cytaty z badanych grup respondentów (profesorowie, naukowcy po doktoracie, studenci studiów doktoranckich).

Istotne wydaje się podkreślenie, iż niniejsze badanie rozwoju GCR koncentruje się głównie na programach studiów doktoranckich $\mathrm{w}$ dziedzinie edukacji. Takie zawężenie zakresu opracowania wynika z zamiaru dogłębnego zrozumienia badanego zjawiska. O ile rzeczywiste przygotowanie badaczy różni się w zależności od dyscypliny naukowej, mnożenie badanych dyscyplin na obecnym etapie badań potencjalnie skomplikowałoby proces badawczy, co z kolei mogłoby negatywnie odbić się na realizacji określonych w tym artykule celów. Ponadto, zainteresowanie rozwojem studentów studiów doktoranckich jako GCR było spowodowane faktem, iż często są oni traktowani jako początkujący badacze, od których oczekuje się przejścia od konsumentów do producentów wiedzy ${ }^{18}$ oraz z przypisywanego im znaczenia we współczesnej, opartej na wiedzy gospodarce ${ }^{19}$. Nicolas opisując studentów studiów doktoranckich jako przyszłych twórców wiedzy stwierdził, że „Naukowcy przygotowujący się do pracy badawczej (ang. researchers in the making $)^{20}$ są zdecydowanie najważniejszymi «wehikułami» transferu badań uniwersyteckich do społeczeństwa". W podobnym nurcie The Association of Commonwealth Universities podkreśla znaczenie wsparcia dla naukowych nowicjuszy w ramach inwestycji badawczych ${ }^{21}$.

\section{Wyniki badań}

Struktura poniższej części tekstu wyznaczona jest przez trzy główne tematy wyłonione podczas analizy jakościowej. Relacjonowane tematy są związane $\mathrm{z}$ odpowiednimi badaniami międzynarodowymi tak, aby bezpośrednio umiejscowić opinie respondentów na szerszym tle opracowań naukowych i odnieść się do celów prezentowanego artykułu.

${ }_{18}$ B.E. Lovitts, Being a good course-taker is not enough: A theoretical perspective on the transition to independent research, Studies in Higher Education, 2005, 30, s. 137-154.

${ }_{19}$ L. Evans, Developing the European researcher: "Extended" professionality within the Bologna process, Professional Development in Education, 2010,36, s. 663-677. doi:10.1080/19415251003633573, [data dostępu: 13.02.2018].

${ }^{20}$ J. Nicolas, Researchers for tomorrow, University Affairs, 2008, January 7, http:/ / www.universityaffairs.ca, s. 10, [data dostępu: 13.02.2018].

${ }^{21}$ The Association of Commonwealth Universities Investing in the next generation of researchers, London 2016, https://www.acu.ac.uk/publication/download?publication=676, [data dostępu: 13.02.2018]. 


\section{Wiedza i umiejętności, których oczekuje się od GCR}

W opiniach respondentów, badawcze kompetencje w ujęciu globalnym wymagają specyficznej wiedzy i umiejętności. W odniesieniu do wiedzy, respondenci zidentyfikowali następujące obszary: wszechstronna wiedza dotycząca własnej dziedziny naukowej oraz z zakresu: podstaw metodologii badań, zrozumienia różnic kulturowych, polityki edukacyjnej $\mathrm{w}$ aspekcie globalnym, praw człowieka i zasad etycznych z uwzględnieniem specyficznych kontekstów. Poniżej przytoczono reprezentatywne próbki wypowiedzi respondentów ( $w$ nawiasach podano numery przypisane kolejnym respondentom danej kategorii).

Globally competent researchers potrzebuja wiedzy z zakresu ich zainteresowań, ugruntowanej wiedzy w dziedzinie zaawansowanych metod badawczych, wiedzy dotyczacej problemów naukowców z innych krajów/kultur. Dodatkowo, GCR musza wykazywać zrozumienie dla praw człowieka i zasad etycznych w różnorodnych kontekstach. Profesor [8]

Zasadniczo taki naukowiec powinien być dobrze obeznany ze swoja własna dyscyplina, posiadać dogłębna wiedzę z zakresu metodologii badawczej, rozumieć różne kultury i posiadać wiedze o nich. Globalna rzeczywistość wymaga od naukowców, aby poruszali się poza granicami własnej kultury i z właściwym szacunkiem wspótpracowali z tymi, którzy nie podzielają ich systemu wartości i akceptowanych norm. Naukowiec po doktoracie [3]

Analiza danych ukazuje, iż większość respondentów ze wszystkich trzech grup uważa, że oprócz wiedzy z zakresu własnej dziedziny badawczej i naukowej metodologii, GCR potrzebują tak zwanej inteligencji kulturowej. Literatura naukowa definiuje ją jako wielowymiarową zdolność, pozwalającą na efektywne funkcjonowanie w obrębie nowych i różnorodnych kulturowo kontekstach, a zawiera w sobie elementy kognitywne, motywacyjne i behawioralne ${ }^{22}$. Komponent kognitywny odnosi się do wiedzy, świadomości i samo-świadomości, motywacyjny - do wytrwałości i odpowiedniego definiowania celów związanych z kulturową interakcją ${ }^{23}$ Z kolei element behawioralny jest ściśle związany z działaniami i umiejętnościami służącymi dostosowaniu zachowania do środowiska kulturowego. $W$ tym aspekcie uczestnicy twierdzili, że GCR powinien mieć pewne szczególne

${ }^{22} \mathrm{~K} . \mathrm{Ng}$, C. Earley, Culture + intelligence: Old constructs, new frontiers, Group \& Organizational Management, 2006, 31, s. 4-19.

${ }^{23}$ C. Earley, R. Peterson, The elusive cultural chameleon: Cultural intelligence as a new approach to intercultural training for the global manager, Academy of Management Learning \& Education, 2004, 3, s. 100-115. 
umiejętności. Przede wszystkim, należą do nich otwartość, elastyczność, cierpliwość, pracowitość i umiejętność pracy w grupie. Po drugie, powinien posiadać zaawansowane umiejętności w zakresie nowych technologii, komunikacji, języków obcych. Po trzecie, istotna jest zdolność integrowania wiedzy z różnych dyscyplin, praca wewnątrz danej kultury i w środowisku wielokulturowym, wrażliwość kulturowa, szacunek dla różnych punktów widzenia i systemów etycznych, gotowość dzielenia się wiedzą i doświadczeniem. Wymienione powyżej umiejętności zostały uznane za podstawowe w prowadzeniu badań w erze globalizacji. Jak ujęła to jedna z osób uczestniczących w badaniu:

Oprócz znajomości metodologii badań, GCR potrzebuja m.in. empatii, szacunku dla lokalnych i różnych światopoglądów, otwartego umystu, elastyczności, cierpliwości, wytrwatości i pracowitości. Ponadto, powinni posiadać rozwinięte poczucie wrażliwości kulturowej i wysoki poziom inteligencji kulturowej. Profesor [5]

Podobne opinie odnajdujemy u innych respondentów.

Otwartość na inne kultury, ludzi, religie, znajomość języków obcych i odmiennych tradycji badawczych, zdolności komunikacyjne i empatia, zrozumienie różnic kulturowych, wiedza z zakresu nowoczesnych metod badawczych i podejść epistemologicznych. Student - doktorant [2]

Poza kompetencjami potrzebnymi do funkcjonowania jako naukowiec lokalnie, konieczne sa jeszcze takie, które sa potrzebne dla globalnego funkcjonowania: wrażliwość kulturowa, zdolność pracy w odmiennej kulturze i środowisku wielokulturowym, umiejętność skutecznej komunikacji w różnorodnych kontekstach $i$ otwartość. Profesor [6]

Udzielone odpowiedzi domagają się głębszej refleksji dotyczącej pożądanych i oczekiwanych postaw oraz zachowań GCR. Biorąc pod uwagę uprzywilejowaną pozycję naukowców, szczególna uwaga powinna być poświęcona aspektowi moralnemu funkcjonowania GCR w instytucjach edukacji wyższej. Koncentracja na tym aspekcie pozwoliłaby zbadać i ocenić, w jaki sposób programy studiów doktoranckich starsi badacze i zwierzchnicy naukowców przekazują owe umiejętności swoim następcom.

Badania Levine' a ${ }^{24}$ wskazują, iż większość programów uniwersyteckich w Stanach Zjednoczonych nie wyposaża badaczy w niezbędne umiejętności, a braki w tym zakresie wynikają z nieodpowiednich zasobów pozwalających wspierać studentów studiów doktoranckich, niedoboru naukowców,

\footnotetext{
${ }^{24}$ A. Levine, Educating researchers, Washington 2007.
} 
którzy byliby efektywnymi badaczami i doświadczonymi mentorami, braku rygorystycznych standardów i niejasności oczekiwań wobec studentów doktorantów. Zrozumienie rodzajów kompetencji, jakich potrzebują GCR w coraz bardziej wymagającym współpracy i skomplikowanym kontekście badań naukowych stanowi jedynie pierwszy etap. Następnym powinno być zrozumienie, jakie są możliwości przygotowania początkujących badaczy oraz wzmocnienie tych odnoszących się do wiedzy i umiejętności. W nawiązaniu do tego problemu, w następnej części opisano bieżącą sytuację $\mathrm{w}$ instytucjach, z których pochodzą respondenci.

\section{Edukacyjne możliwości przygotowania GCR}

Respondenci wskazali na różnorodne możliwości edukacyjne sprzyjające przygotowaniu GCR. Niemniej jednak, ograniczone wypowiedzi studentów studiów doktoranckich mogą wskazywać na odczuwany przez nich brak świadomości dotyczącej możliwości kształcenia badawczego lub na ich niezadowolenie odnośnie istniejących przestrzeni i praktyk edukacji badawczej. Jedna osoba $\mathrm{z}$ tej grupy respondentów wyraziła się w następujący sposób: Nie wydaje mi się, abyśmy w tym momencie posiadali w naszej instytucji GCR [5] Ponadto, większość profesorów i naukowców po doktoracie stwierdziła, że ich instytucje wymagają poważnych zmian w odniesieniu do zapewnienia rozwoju dla GCR. Większość respondentów za istotne w odniesieniu do globalnych kompetencji naukowców uznała: oferowanie kursów i warsztatów dotyczących metod badawczych, zapewnienie szkoleń w zakresie etyki badawczej, tworzenie możliwości asystentur badawczych, zapewnienie superwizji i mentoringu podczas całego procesu badawczego, zapewnianie funduszy badawczych, zachęcanie do mobilności pracowników i studentów, promowanie programów wymiany studenckiej i międzynarodowych sieci współpracy, uczenie się od zagranicznych wykładowców różnych kultur i systemów edukacyjnych w celu lepszego zrozumienia własnego kontekstu. Wybrane wypowiedzi w tej części badania zawierają poniższe opinie.

Uniwersytety stały się częścia polityki międzynarodowej, naukowcy maja szansę uczestnictwa w globalnych społecznościach badawczych, udzielaja swojego głosu w ważnych kwestiach edukacyjnych. Od uniwersytetów oczekuje się, że będą wspomagały rozwój swojej kadry. Wostatnich latach podpisano wiele porozumień umożliwiajacych mobilność pracowników uczelni i studentów, co w konsekwencji przyczynia się do sprawniejszego obiegu informacji i networkingu. Dzięki temu procesowi nawiazuja się nowe relacje, a ich uczestnicy nabywaja nowe umiejętności. Niemniej jednak ów proces jest wciąz źle zorganizowany i momentami dość trudny. Profesor [4] 
Organizowane sa warsztaty badawcze, kursy metodologii badań jakościowych i ilościowych, odbywa się opracowywanie założen badawczych pod okiem mentora, asystentury badawcze, podczas których studenci towarzysza doświadczonym badaczom. Wszystkie te działania przyczyniaja się do wzmocnienia wiedzy i umiejętności studentów w określonych obszarach badawczych, metodologiach, w zakresie kwestii etycznych, wspótpracy i technologii informacyjnej. Naukowiec po doktoracie [6]

Nie sądze, aby koncepcja GCR była stosowana i rozumiana w szerokim zakresie w mojej instytucji i kraju, chociaż można zaobserwować pewne symptomy postępu na mojej uczelni. Jednym z nich jest promowanie internacjonalizacji skutkujacej wymianą naukowców i nabywaniem kompetencji międzykulturowych. Niekiedy problemem jest słaba znajomość angielskiego, która uniemożliwia nabywanie takich doświadczeń tym, którzy ich najbardziej potrzebują. Naukowiec po doktoracie [5]

Wymienione powyżej możliwości reprezentują bieżące przestrzenie i praktyki mające zastosowanie w instytucjach respondentów podczas kształcenia przyszłych badaczy, głównie studentów studiów doktoranckich w zakresie edukacji. Z odpowiedzi wynika, że poza formalnymi przestrzeniami, takimi jak kursy i warsztaty, również zaangażowanie w inne działania edukacyjne zapewnia warunki do kształcenia dla przyszłych naukowców ${ }^{25}$. Na równi z mobilnością międzykulturową, respondenci wskazywali na znaczenie odpowiedniej superwizji i mentoringu. Według Miller i Salkind,

W procesie stawania się kompetentnym naukowcem nie ma dróg na skróty. Wymaga to bardzo wiele czasu i praktyki w szerokim znaczeniu tego słowa. Im liczniejsze doświadczenia w różnych środowiskach tym większe kompetencje ${ }^{26}$.

Podobne opinie znajdujemy u Lee i Roth, którzy twierdzą, iż „,zaangażowanie i doświadczenie to dwie strony tej samej monety"27.

Nie ma wątpliwości, że instytucje edukacji wyższej powinny zaangażować się w systemowe planowanie wysokiej jakości kształcenia badawczego. Choć rezultat naukowego rozwoju trudno przewidzieć, możliwe jest stworzenie warunków, w których GCR mogliby osiągać pełnię swoich możliwości. Podobnie jak u respondentów, przykłady z literatury ${ }^{28}$ ukazują ważność za-

${ }^{25}$ J. Nicolas, Researchers for tomorrow, University Affairs, 2008, January 7, http:/ / www.universityaffairs.ca, [data dostępu: 13.02.2018].

${ }^{26}$ D.C. Miller, N.J. Salkin, Basic research design, [w:] Handbook of research design \& social measurement, eds. 6th, red. D. C. Miller and N. J. Salkind, 13-16, Thousand Oaks 2002, s. 15.

27 S. Lee, W.M. Roth, Becoming and belonging: Learning qualitative research through legitimate peripheral participation, Forum: Qualitative Social Research, 2003, 4(2), http:/ /www.qualitative-research.net, par. 11, [data dostępu: 13.02.2018].

${ }^{28}$ E.K. Niemczyk, A case study of doctoral research assistantships: Access and experiences of full-time and part-time education students, St. Catharines, ON 2015; J.P. Rossouw, E.K. Niemczyk, 
angażowania studentów-doktorantów w społeczność badawczą i bezpośrednie praktyczne kształcenie badawcze. McWey, Henderson i Piercy ${ }^{29}$ dowodzą, że rozwój naukowy w programach studiów doktoranckich oznacza nie tylko kursy z metodologii badawczej i stworzenie założeń pracy, ale także szeroki zakres możliwości edukacyjnych, podczas których studenci mogą łączyć i stosować wiedzę teoretyczną z praktyką badawczą. W raporcie APEC/ Deloitte $(2010)^{30}$ także wyraża się poparcie dla idei jednoczesnego kształcenia i prowadzenia badań oraz sugeruje, aby studenci możliwie wcześnie dołączali do zespołów badawczych w celu rozwijania swoich umiejętności.

\section{Wyzwania związane z przygotowaniem GCR}

W celu wzmocnienia możliwości kształcenia istotne jest zrozumienie istniejących wyzwań i ograniczeń, z których najczęściej wskazywanym przez respondentów był brak funduszy na wsparcie naukowców, w tym mobilności studentów, konferencje i pomoc dla młodych naukowców. Dwóch respondentów wskazało na bieżącą sytuację polityczną w ich krajach jako czynnik ograniczający rozwój uczelni wyższych. Kilku uczestników badania zwróciło uwagę na przeciążenie obowiązkami dydaktycznymi i presję wykazania się publikacjami, co ograniczało czas, który mogliby poświęcić na mentoring i wsparcie początkujących, przyszłych naukowców. Inne wyzwania wskazane przez respondentów to: koncentracja na badaniach krajowych zamiast międzynarodowych i brak projektów interdyscyplinarnych. Reprezentatywne próbki wypowiedzi osób badanych znajdują się poniżej.

Wsparcie dla studentów jest niewielkie, a pracownicy naukowi sąrzeciążeni praca i presja prowadzenia badań przy bardzo matym finansowaniu. Wniektórych dziedzinach bardzo małe jest wsparcie dotyczace udziału w konferencjach, co przyczynia sie do nierówności. Niektórzy wysoka ranga profesorowie zagarniaja dla siebie wszystkie fundusze na badaniailekceważą potrzebę wspierania młodej kadry, hamując ich rozwój. Profesor [2]

Mój uniwersytet to instytucja skupiona głównie na kształceniu, początkująca na polu badań naukowych. Takie badania podejmowane sa zwykle na mała skale, bez finansowania przez jakiekolwiek agendy o zasiegu międzynarodowym, stąd wiele wyzwań $z$ tym zwiąanych. Nie sądzę abyśmy mieli możliwości rozwoju GCR, a jeśli miałoby to się stać, bytoby ograniczone do bardzo specyficznych obszarów badań. Profesor [3]

Regulated research learning spaces: An ethical-juridical perspective from South African and Canadian contexts, South African Journal of Higher Education, 2016, 29(6), s. 279-292.

${ }^{29}$ L.M. McWey, T.L. Henderson, F.P. Piercy, Cooperative learning through collaborative faculty-student research teams, Family Relations, 2006, 55, s. 252-262, doi:10.1111/j.1741-3729.2006. 00374.x, [data dostępu: 13.02.2018].

${ }^{30} \mathrm{P}$. Lamblin $\mathrm{i}$ in., Skills and competencies needed in the research field. 
Główne wyzwania związane sa z trudna sytuacją międzynarodowa. Kraje europejskie, szczególnie w Europie Wschodniej, maja tendencję do zamykania się w obrębie swoich własnych kultur i tradycji. Taki proces prowadzi do sceptycznego podejścia do kwestii globalnych, ponieważ sa one postrzegane jako zagrożenie dla kultur narodowych. Naukowiec po doktoracie [4]

Większość respondentów za wyzwanie uznała ograniczone fundusze, a co za tym idzie - ograniczone źródła naukowego rozwoju studentów. Zatem, nawet jeśli opiekunowie naukowi pragnęliby włączyć swoich studentów w międzynarodową społeczność naukową, są ograniczani wewnętrznym finansowaniem naukowego rozwoju i niezwykle trudnym do zdobycia finansowaniem zewnętrznym ${ }^{31}$. Istotne jest przy tym zauważenie, że współudział nowicjuszy i doświadczonych naukowców, a także zaangażowanie w społeczności badawcze przyczynia się walnie do rozwoju tożsamości naukowej ${ }^{32}$. Znaczna liczba respondentów wskazała na dużą liczbę godzin dydaktycznych i presję na publikowanie, co znajduje odzwierciedlenie w literaturze, odnoszącej się do braku czasu kadry uczelnianej spowodowanej obciążeniem dydaktycznym, koniecznością prowadzenia badań i publikacji, a także sporymi obowiązkami administracyjnymi i działalnością na rzecz uczelni ${ }^{33}$. W międzynarodowej literaturze znajdują się odniesienia dotyczące opiekunów naukowych, od których oczekuje się, że będą wspierać rozwój początkujących naukowców ${ }^{34}$ i zapewniać im możliwości kształcenia, które zwiększą ich umiejętności badawcze i pozytywnie wpłyną na samoidentyfikację jako naukowców ${ }^{35}$. Niemniej jednak, taki proces może okazać się wyzwaniem, jeśli obciążenia dydaktyczno-naukowe zajmują większość ich czasu.

\section{Znaczenie przeprowadzonego badania}

Rezultaty przedstawione w niniejszym artykule wskazują na potrzebę silniejszego nacisku na przygotowanie przyszłych naukowców. Wyniki sugerują, iż europejskie instytucje edukacji wyższej powinny wziąć pod uwagę

31 E.K. Niemczyk, A case study of doctoral research assistantships.

32 K. Pyhältö, J. Stubb, K. Lonka, Developing scholarly communities as learning environments for doctoral students, International Journal for Academic Development, 2009, 14, s. 221-232.

33 A.E. Austin, Creating a bridge to the future: Preparing new faculty to face changing expectations in a shifting context, The Review of Higher Education, 2003, 26, s. 119-144; R. Deem, K. Brehony, Doctoral students' access to research cultures - Are some more unequal than others? Studies in Higher Education, 2000, 25, s. 149-165. doi:10.1080/713696138.

34 K.A. Strike i in., Ethical standards of the American Educational Research Association: Cases and commentary, American Educational Research Association, Washington 2002.

35 A.L. Grundy, Learning experiences and identity development as a research assistant, St. Catharines, ON 2004. 
oczekiwania wobec GCR i ocenić efektywność ich dotychczasowych sposobów kształcenia naukowego oraz związanych z nimi wyzwań. Jesteśmy przy tym świadomi, że potrzebne są dalsze badania w tym zakresie, gdyż kwestionariusze ankiety zawierające pytania otwarte nie pozwoliły na dogłębne zbadanie problemu. W następnym etapie badań wskazane byłoby zatem wykorzystanie wywiadów.

Jak wynika z zaprezentowanej literatury, rola badań naukowych na uniwersytetach wzrasta i oczekiwania wobec naukowców stają się coraz bardziej złożone. W tej sytuacji istotne byłoby przemyślenie bieżącego kształcenia naukowego na uczelniach wyższych. Krótko rzecz ujmując, jeśli kraje europejskie chcą być konkurencyjne globalnie w zakresie możliwości badawczych, należy poświęcić szczególną uwagę przygotowaniu GCR. Jednocześnie należy wziąć pod uwagę, że kraje europejskie znajdują się w różnych fazach rozwoju, co dotyczy infrastruktury, kapitału ludzkiego, czy możliwości finansowych. Prezentowane badanie dostarcza wglądu w obszar kompetencji zidentyfikowanych przez respondentów i potrzebnych do prowadzenia badań o wysokiej jakości. Wśród kompetencji pożądanych w odniesieniu do GCR wymienili oni: wszechstronną wiedzę w dziedzinie, którą się zajmują, znajomość metodologii oraz kompetencje związane z inteligencją kulturową. Rezultaty wskazują także, że przygotowanie przyszłych GCR-sów wymaga rozwoju umiejętności komunikacyjnych, interpersonalnych i znajomości nowoczesnych technologii. Opinie respondentów wskazują, jakie rodzaje przestrzeni kształcenia pozwalają na nabycie różnych kompetencji badawczych. Naturalnym następnym krokiem powinno być zbadanie, poprzez jakie poszczególne praktyki i doświadczenia kompetencje te mogą być przekazywane, bowiem prawdziwy rozwój takich wartości, jak wrażliwość kulturowa czy empatia wymaga przestrzeni na refleksję i krytyczną analizę. Mogłaby to być przestrzeń $\mathrm{w}$ ramach programów, w których początkujący badacze mieliby możliwość dokonać naukowej samooceny, podejść refleksyjnie do kwestii nierówności systemowych, czy ocenić poziomy niesprawiedliwości i dyskryminacji w różnorodnych kontekstach. Promowanie szacunku dla różnorodności może odbywać się poprzez filmy, analizę tekstów, czy dyskusje w czasie warsztatów lub nieformalnych rozmów ze współpracownikami. Wartości związane ze sprawiedliwością społeczną mogą być także przekazywane poprzez korzystanie z kampanii w mediach społecznościowych czy akcji podnoszących świadomość dotyczącą kwestii społecznych. Ważne jest ponadto stworzenie przestrzeni, w której młodzi naukowcy mogliby dzielić się swoimi pomysłami i swobodnie wyrażać różnice zdań, kształcąc $\mathrm{w}$ ten sposób umiejętność rozwiązywania konfliktów i akceptację dla istnienia różnych perspektyw. 
Innym aspektem wartym bliższej analizy w kontekście wzmocnienia jakości kształcenia naukowego jest kwestia zidentyfikowanych przez respondentów wyzwań. Do tych z nich dotyczących braku funduszy nie jest łatwo się odnieść. Jednakże, jako że światowy kontekst zmienia się w kierunku sprzyjającym gospodarce opartej na wiedzy i innowacyjności, prywatne i publiczne źródła finansowania, choć niełatwe do zdobycia w warunkach konkurencji, powinny zostać zwiększone w celu wspierania nowatorskich odkryć badawczych i naukowej doskonałości. Ponadto, promowanie zaangażowania początkujących naukowców w globalną społeczność naukową wymaga środków wspierających ich mobilność. Można ten cel osiągnąć poprzez zapewnienie dodatkowych funduszy dla studentów doktorantów poprzez nowe i poszerzone formy programów stypendialnych oraz zwiększenie nakładów na granty badawcze.

Instytucje edukacji wyższej są zachęcane do ewaluacji istniejących już regulacji i praktyk związanych z finansowym wsparciem naukowców. Nowe praktyki mogłyby być ustanowione tak, aby odnosiły się do systemu zachęt i celów związanych z potrzebami rozwojowymi początkujących badaczy. Wyznaczenie instytucjonalnego wsparcia dla rozwoju GCR mogłoby pomóc w kształtowaniu kultury badawczej cenionej przez naukowców na wszystkich etapach ich kariery. Zapewniałoby też utrzymanie się motywacji obiecujących naukowców, nakierowanej na kontynuację rozwoju globalnych kompetencji i efektywności.

Nie ulega wątpliwości, iż rola naukowego superwizora jest znaczna i istnieje długa lista umiejętności, którą doświadczeni naukowcy powinni mieć $\mathrm{w}$ celu asystowania początkującym kolegom. Zasadna wydaje się sugestia, iż pracownicy naukowi powinni aktualizować własne umiejętności (np. mentorskie) w celu zapewnienia wysokiej jakości kształcenia naukowego. Pozostaje pytanie, czy taki zawodowy rozwój czynnych naukowców winien: a) należeć do obowiązków zatrudniającej ich instytucji, b) leżeć w gestii indywidualnego pracownika, czy c) odpowiedzialność powinna być podzielona.

Podsumowując, w obliczu złożonej rzeczywistości i komplikujących się kwestii społecznych coraz większa wartość przypisywana jest badaniom jako ważnemu wynikowi końcowemu edukacji wyższej i szerzej - rozwojowi społeczeństwa. Jednakże, owa wartość nie została w pełni przyswojona przez europejską kulturę instytucjonalną, w której budowanie możliwości badawczych i rozwój GCR byłby traktowany priorytetowo i wspierany w wystarczającym stopniu. Prezentowany tekst jest przyczynkiem do dyskusji na temat wzmocnienia rozwoju początkujących GCR, stanowiących niezbędne źródło nowatorskich badań i rozwiązywania istotnych problemów społecznych. 


\section{BIBLIOGRAFIA}

Austin A.E., Creating a bridge to the future: Preparing new faculty to face changing expectations in a shifting context, The Review of Higher Education, 2003, 26.

Boud D., Lee A., Framing doctoral education as practice, [w:] Changing practices of doctoral education, red. D. Boud, A. Lee, Routledge, Abingdon 2009.

Braun V., Clarke V., Using thematic analysis in psychology, Qualitative Research in Psychology, 2006, 3(2), http://dx.doi.org/10.1191/1478088706qp063oa, [data dostępu: 13.02.2018].

Brogt E., Astronomy education: Becoming a hybrid researcher, Journal of Research Practice, 2007, 3(1), Article M2, http://jrp.icaap.org/index.php/jrp, [data dostępu: 13.02.2018].

Chubb I., Productivity, industry engagement and the PhD workforce. Keynote address for the AMSI Accelerate Australia Conference, Melbourne February 2013, http:/ /www. chiefscientist.gov.au/2013/02/productivity-industry-engagement-and-the-phd-workforce/, [data dostępu: 13.02.2018].

Connell H. (red.), Part 1: Addressing the research challenge in higher education, [w:] University research management: Meeting the institutional challenge, Organisation for Economic Cooperation and Development, Paris 2004.

Deem R., Brehony K., Doctoral students' access to research cultures - Are some more unequal than others? Studies in Higher Education, 2000, 25.

Deem R., Mok K.H., Lucas L., Transforming higher education in whose image? Exploring the concept of the 'world-class' university in Europe and Asia, Higher Education Policy 2008, $21 / 1$.

Earley C., Peterson R., The elusive cultural chameleon: Cultural intelligence as a new approach to intercultural training for the global manager, Academy of Management Learning \& Education, 2004, 3.

Economic and Social Research Council, Strategic plan 2009-2014, 2014, http://www.esrc. ac.uk/news-and-events/publications/strategic-plan/index.aspx, [data dostępu:13.02. 2018].

European Commission, PEOPLE: Training and career development of researchers, 2015, http:/ / ec.europa.eu/research/fp7/index_en.cfm?pg=people, [data dostępu: 13.02.2018].

Evans L., Developing the European researcher: "Extended" professionality within the Bologna process, Professional Development in Education, 2010, 36, [data dostępu: 13.02.2018].

Given L.M., Interpretive Research, [w:] The SAGE encyclopedia of qualitative research methods, red. L.M. Given, Sage, Thousand Oaks 2008.

Grundy A.L., Learning experiences and identity development as a research assistant, Unpublished master's thesis, Brock University, St. Catharines, ON 2004.

Hallet F., Fidalgo P., Educational research capacity building in the European Union: A critique of the lived experiences of emerging researchers, European Educational Research Journal, 2014, 13.

Lamblin P., Etienne C., Meunier M.-Ch., Bancal M., Lenot O., Davo J., Skills and competencies needed in the research field: Objectives 2020, APEC/Deloitte, Paris 2010,https:/ / recruteurs.apec.fr/files/live/mounts/media/medias_delia/documents_a_telecharger/etudes_apec/skills_and_competencies_needed_in_the_research_field_objectives_2020/6185e35c6eef813aadaf2ee2bac10c6c.pdf [data dostępu: 13.02.2018].

Lee S., Roth W.M., Becoming and belonging: Learning qualitative research through legitimate peripheral participation, Forum: Qualitative Social Research, 2003, 4(2), http:/ /www. qualitative-research.net, par. 11, [data dostępu: 13.02.2018].

Levine A., Educating researchers, The Education Schools Project, Washington, DC 2007. 
Lovitts B.E., Being a good course-taker is not enough: A theoretical perspective on the transition to independent research, Studies in Higher Education, 2005, 30.

McGinn, M K., Tilley S.A., Research ethics on the ground: Partnerships, practices, and plans in global population health - A collective case study of ethics issues and challenges, Paper presented at Innovations in Global Health Research - Global Social Justice and the Social Determinants of Health: Setting the Course for the Future, Ottawa, ON, October 2012.

McWey L.M., Henderson T.L., Piercy F.P., Cooperative learning through collaborative facultystudent research teams, Family Relations, 2006, 55 [data dostępu: 13.02.2018].

Miller D.C., Salkind N.J., Basic research design, [w:] Handbook of research design $\mathcal{E}$ social measurement, eds. $6^{\text {th }}$, red. D.C. Miller and N. Salkind, 13-16, Sage, Thousand Oaks 2002.

Mohrman K., Ma W., Baker D., The research university in transition: The emerging global model, Higher Educational Policy, 2008, 21.

$\mathrm{Ng}$ K., Earley C., Culture + intelligence: Old constructs, new frontiers, Group \& Organizational Management, 2006, 31.

Nicolas J., Researchers for tomorrow, "University Affairs" 2008, January 7, http:/ / www.universityaffairs.ca, [data dostępu: 13.02.2018].

Niemczyk E.K., A case study of doctoral research assistantships: Access and experiences of full-time and part-time education students, Unpublished doctoral thesis. Brock University, St. Catharines, ON 2015.

Niemczyk E.K., Developing Globally Competent Researchers: International Perspective, South African Journal of Higher Education, 2018, 32(4).

Pyhältö K., Stubb J., Lonka K., Developing scholarly communities as learning environments for doctoral students, International Journal for Academic Development, 2009, 14.

Rossouw J.P., Niemczyk E.K., Regulated research learning spaces: An ethical-juridical perspective from South African and Canadian contexts, South African Journal of Higher Education, 2016, 29(6).

Strike K.A., Anderson M.S., Curren R., van Geel T., Pritchard I., Robertson E., Ethical standards of the American Educational Research Association: Cases and commentary, American Educational Research Association, Washington DC 2002.

Szostak R., Research skills for the future: An interdisciplinary perspective, Journal of Research Practice, 2013, 9(1), Article V3, http://jrp.icaap.org/index.php/jrp/article/ view/385/308, [data dostępu: 13.02.2018].

The Association of Commonwealth Universities, Investing in the next generation of researchers, London, 2016, https://www.acu.ac.uk/publication/download?publication=676, [data dostępu: 13.02.2018].

Walker G.E., Golde C.M., Jones L., Conklin Bueschel A., Hutchings P., The formation of scholars: Rethinking doctoral education for the twenty-first century, CA: Jossey-Bass, San Francisco 2008.

Weijters B., Geuens M., Baumgartner H., The effect of familiarity with the response category labels on item response to Likert scales, Journal of Consumer Research, 2013, 40. 